\title{
Role of herbs for elevating immunity against SARS-CoV-2: a concise review
}

\author{
Aashima Anand, ${ }^{1}$ Juhi Saraswat ${ }^{1}$ and Rajan Patel ${ }^{1 *}$
}

\begin{abstract}
COVID-19 has emerged as a dreadful pandemic caused by the virus SARS$\mathrm{CoV}-2$. Though the number of patients recovering from infection is encouraging, sturdy cure is still being researched upon and the effective vaccines are yet to be rigidly resolute. COVID-19 has so far instigated a massive loss of lives globally and even the countries with the most advanced healthcare systems have come under its grasp. Health experts suggest in such case "Prevention is better than cure" which includes an appropriate daily lifestyle and a rugged immune system that could help mankind surmount this peril. This review highlights the importance of influential herbs and their medicinal significance. Biomedical articles were explored from PubMed, Google Scholar, Web of Science for the period of 2010-2021. Guidelines from the Ministry of Ayush (India) were also considered. The Ayurveda does not mention any cure for the novel coronavirus; however, it emphasizes the means of boosting one's immunity. Accordingly, this article highlights some of the role of prevalent Ayurvedic herbs in promoting immunity for combating the novel coronavirus. The herbs in combination with drugs could be utilized for the sake of curtailing the side effects as well as the malefic repercussions of strong synthetic drugs used for treating COVID-19 patients, which would be a paramount leap in the field of Ayurveda as well as western-style medicine. However, the beneficial effects of these traditional medicines and their clinical trials remained to be known. We reviewed the latest updates on traditional medicines proposed for promoting immunity towards COVID-19.
\end{abstract}

Keywords: COVID-19, antiviral agents, Ayurveda, herbal plants, immunity, therapeutic uses
Biophysical Chemistry Laboratory, Centre for Interdisciplinary Research in Basic Sciences, Jamia Millia Islamia, New Delhi-India.

\section{*Correspondence:}

Dr. R. Patel

Biophysical Chemistry Laboratory, Centre for Interdisciplinary Research in Basic Sciences, Jamia Millia Islamia, New Delhi-110025, India Tel.: +91 8860634100;

Fax: +91 1126983409

Email: rpatel@jmi.ac ORCID ID: 0000-0002-3811-2898

Date of first submission, February 12, 2021

Date of final revised submission, July 6, 2021

Date of acceptance, August 7, 2021

This open access article is distributed under a Creative Commons AttributionNon Commercial-Share Alike 4.0 International License

Cite this article as: Anand A, Saraswat J, Patel R. Role of herbs for elevating immunity against SARS-CoV-2: a concise review. Univ Med 2021;40:173-85. doi: 10.18051/UnivMed.2021.v40.176-188 


\section{INTRODUCTION}

The novel COVID-19 pandemic is claiming thousands of human lives worldwide. The World Health Organization is continuously visualizing the pandemic situation globally regarding the spread, morbidity, and mortality rate. According to the recent WHO report of $1^{\text {st }}$ May 2021, a total of $150,989,419$ confirmed cases and $3,173,576$ deaths have been recorded worldwide which figures are expected to increase exponentially in the coming time. ${ }^{(1)}$ The very high mortality is accounted by its easy human to human transmission from close proximity to an infected person through their respiratory droplets or aerosols via sneezing or getting in contact with any surface presenting these. This virus contains a positively charged single-stranded RNA and belongs to the $\beta$-group of coronaviruses. ${ }^{(2)} \mathrm{On}$ the outer surface, the coronavirus exhibits crownlike spikes of glycoprotein, accountable for the attachment of the virus to the host cells' angiotensin-converting enzyme 2 (ACE2) cellular receptors and later through envelope fusion with the cell membrane, the virus detaches the RNA into the host cell. ${ }^{(3)}$ This severe acute respiratory syndrome coronavirus 2 (SARS-CoV-2), comprising the contagion, primarily affects the respiratory system. ${ }^{(4,5)}$ Initially, cases emerged from Wuhan city of China where thousands of patients manifested symptoms of pneumonia that eventually led to the discovery of this virus which apparently originates from bats and which through mutations can infect humans. ${ }^{(6)}$ The initial symptoms include soaring fever, dry cough, shortness of breath, loss of smell (anosmia) besides other uncommon symptoms. ${ }^{(1)}$ Several patients are asymptomatic whereas the effects of the virus can be more prominent in patients with a history of diabetes or heart related disorders. $^{(7)}$

Pandemics are not an unfamiliar plight and tend to emerge intermittently. The only variance emerging with time is the advancement in medication for treating this peculiar persistant infection in order to shield mankind from its harmful effects. Medical therapy employs here in a crucial role for tending to the wellbeing of every suffering individual. The ancient medical system of India, better known as Ayurveda, is being emphasized during these momentous days. Ayurveda is known not only in India but is also followed across the globe due to its appealing trait being the herbs mentioned there, having no side effects either on humans or on the environment. Ayurveda also provides a holistic approach for leading an elementary life. It includes practicing Yogasanas and meditation every day to attain a healthy body as well as mind. Although the Ayurveda does not mention any cure for the novel coronavirus, it emphasizes profoundly on the means of boosting one's immunity. Currently, all countries must team up and collectively fight COVID-19 by practicing hand-hygiene and social distancing. Accordingly, this article highlights some of the prevalent Ayurvedic herbs and their role in promoting immunity for combating the novel coronavirus.

\section{Virus and antiviral agents}

Viruses are intracellular parasites that do not have any metabolic machinery of their own; hence, they cannot multiply by themselves. To do this, they invade the host cells and employ the biochemical mechanisms of the host cell to promote their own growth by replicating new virus proteins and genetic material and in turn attack the host. ${ }^{(8)}$ For the development of a trailblazing tool against any virus, it is fundamental to understand the mode of viral infection, the intervention of which can prompt its containment. The multiplication of any virus inside the host cells comprises of numerous steps: attachment (tethering of virus to the host cell membrane), penetration (infiltration into the cell), un-coating (casting its protein coat), multiplication (virus breeding in the host cells), protein synthesis (protein forming post-genome development), assembly (coating of genetic material by protein), release (liberation of the virus) to destroy other cells of the host. ${ }^{(9)}$ The virus can enter the human body anytime; at the earliest a response is initiated 
by the immune system for combating the invader, the two sub-classes composing the immune system together being intimately associated and functioning in conjugation whenever an immune response is to be activated. The initial classification is referred to as the innate or the non-specific immune system that commences the first arrangement of response. Since the recognition molecules applied by this system are displayed extensively on a wide range of cells, it operates promptly on confronting the virus. The innate immune system allows a generic shield countering detrimental substances and fights utilizing immune cells, in particular, natural killer (NK) cells or the phagocytes that access the body through dermal routes or the digestive system. Macrophage activation as part of the innate immune system can be initiated by the release of various cytokines, for instance interferons. ${ }^{(10)}$ Interferons strengthen endurance of cells to virus contagion and delay the propagation of disease. ${ }^{(11,12)}$ The second classification is named the adaptive, specific, or acquired immune system recognized for producing antibodies to explicitly tackle certain microorganisms, allergens or toxicants the body has hitherto engaged with. Since this sort of immune system is unceasingly acquiring knowledge and adapting, the body could also combat viruses that modify in the course of time. This system exhibits distinctiveness for target antigens. Accustomed responses are established principally on antigen-specific receptors demonstrated on the surfaces of T- and B-lymphocytes. White blood cells (WBCs) are equally essential to the immune system. On discovering any viruses, they initiate an immune response.

The WBCs include lymphocytes, in particular B-cells, T-cells and NK cells. An antiviral agent is a substance that kills a virus or inhibits its ability to multiply and produce new virus and narrows the symptoms. The antiviral agent can either be a drug, synthetic or natural, or an antibody-containing vaccine that can produce defensive or curative effects. These drugs can act at varying steps of the virus life cycle such as virus replication by retarding viral genetic matter from replication, penetration and un-coating by hitching to cell-surface receptors or inhibiting protein synthesis and deliverance. Antiviral drugs usually possess 'wide therapeutic window'. However, the fabrication of an antiviral drug or vaccine is never a facile piece of work. The fundamental justification for this is the engagement of host cells at each step of the life cycle of the virus in question that endangers the host functions. ${ }^{(13)}$ Moreover, the virus changes with time and again undergoing mutations that makes the action of any specific antiviral agent countering it complicated. Blocking of enzyme activity is necessary but if it is only partially effective, then resistant mutations can arise, which is more likely to threaten the host. Once active inside the host cell, the virus has the tendency of replicating rapidly, hence timely diagnosis and commencing of treatment becomes imperative. Concerning the existing COVID-19, the screening of patients is largely being done based on the symptoms being apparent in the patients. At the same time, some broad-spectrum antiviral drugs such as remdesivir, ritonavir, lopinavir, ${ }^{(14)}$ azithromycin, hydroxychloroquine ${ }^{(15)}$ and others or treatments in additional forms such as corticosteroids in the form of dexamethasone (16) and plasma therapy have emerged as effective antiviral drugs ${ }^{(17,18)}$ when used in combination with various other drugs or herbs ${ }^{(19)}$ leading to the remarkable reduction in the symptoms of coronavirus to a large extent and eventually resulting in a recovery of the patient. China has made use of its traditional Chinese medicine (TCM). ${ }^{(20,21)}$ One of the components of this pathway is the herbal products, in combination with various antiviral drugs, that have shown a high recovery rate amongst coronavirus patients. TCM largely focuses on the overall well-being of the body, rather than emphasizing on treating a particular ailment. The medicines are not a specific herb but comprise of miscellaneous herbal plant products, in formulas selected by and large depending on the individual's need and ailment, in the form of teas, capsules, or powders. Their 
main focus involves detoxifying preparations and lung cleanser herbal treatments since pneumonia was the highlighted symptom of COVID-19 infection in China. ${ }^{(22,23)}$

Till date no reliable cures have been developed for this noxious disease. The only way out for saving the mankind from the torment is the vaccination drive being conducted globally. According to World Health Organization (WHO), as on $19^{\text {th }}$ March, 2021, at least 7 vaccines have been accepted for emergency use worldwide after successful completion of trials whereas more than 200 auxiliary vaccine contenders are in the development stage, of which more than 60 are in the clinical development phase and a few are in the human trial phase after positive trials. ${ }^{(24)}$ Even then, patients with COVID-19 are being cured, although there is no certain drug for it yet. Taking this into consideration, it is encouraged to follow the best prevention tip against the virus, which is strengthening the body's natural defense system or in other words the immunity of an individual, rather paying heed to it being baneful.

\section{Indian herbs and their significance against} SARS-CoV-2

The alarming death rates across countries owing to the novel coronavirus have somehow led to hysteria among the population worldwide since no reliable drug or vaccine is explicitly available for it. The best remedy against this novel virus, which is being laid out in the form of suggestions by numerous nations across the world, is for the individuals to follow a healthy diet in order to improve their immunity to protect themselves from being susceptible to this disease. ${ }^{(25-27)}$ Ethnopharmacology becomes a budding concept in these times since diving into the vast pool of knowledge of botanical drugs is called for during this hour of crisis. Plant-based medicines are an integral part of the Indian medicine system and sculpt a requisite element of our culture. For centuries, this comprehension has been used enormously as a pointer for drug development. ${ }^{(28-30)}$ Traditions like Ayurvedic, Chinese, Kampo, Unani, Iranian, and many more have been inherited by every generation and conceptualized in a distinct manner by each of them. Even the WHO recognizes the gravity of the preservation and acknowledgement of all these ancient medicinal systems. ${ }^{(31)}$ Indian ancient and sacred scriptures are laden with investigations involving traditional use of herbal plants and comprehension of their risks and benefits for mankind and report close to 800 plants as medicinal ones. According to the WHO, approximately $80 \%$ of the population dwelling in developing countries relies on these traditional approaches of herbal remedies for their therapeutic needs. ${ }^{(32)}$ It is estimated that in India, over 6000 plants are in use as traditional and herbal medicines. ${ }^{(33)}$ The foremost rationality backing it is the cost-effectiveness of these herbal products since these are present in ample quantities and no considerable manipulation from their native manifestation is desired. Also, minimum side effects are perceived by employing these herbal plant products in remedial utilization. Typical ailments like common cold, flu, fever, cough, microbial or skin infections, hypertension, asthma and others are effortlessly cured using these practices, whereas strenuous maladies comprising diabetes, depression, stress, heart disease, cancer, tuberculosis and many more have the remedies for their prevention and management in these practices. ${ }^{(34,35)}$ However, the key hindrance involves the scientific study of the intricate chemical constituents of these herbal products, demanding their extraction and further investigations since there is never an active sole component involved but rather complex modules creating enormous structural complications. Every plant consists of primary and secondary metabolites that are involved in numerous functions of the plant. Primary metabolites hold significance in the basic obligations of the plant including its cell division, glycolysis, growth and so on and encompass carbohydrates, proteins, amino acids, chlorophyll etc., whereas the commercial importance of these herbal plants lies in their secondary metabolites which are of prime fascination by virtue of their possession of 
bioactive metabolites such as alkaloids, terpenes, phenolics, lipids and others. ${ }^{(32)}$ Even the supplementary assets of a plant, such as fragrance, as natural dying agents, flavoring agents or natural insecticides or herbicides, are all associated with these secondary metabolites. The antioxidant, antimicrobial, antidiabetic, anticancer and various other properties are all owing to these secondary metabolites, be it their presence in the roots, seeds, stems, leaves, barks, flowers, or fruits of the concerned plant. ${ }^{(36)}$ These are accumulated in scant quantities in plants and hence the process involving their extraction, purification, separation, identification, and eventual studies is a major root of concern which in a way limits the use of the plant as a therapeutic product. Each class of secondary metabolites is responsible for discrete contribution. For example, alkaloids dominate antimicrobial, stimulant properties, flavonoids are accountable for antioxidant, antiinflammatory, anticancer, anti-allergic measures, and so on. ${ }^{(37,38)}$

Ayurveda is the Indian ancient system of healthcare recommending what practices to comply with for embracing a holistic health as well as accomplishing a vigorous immunity towards procuring a profound life aimed at achieving positive health and longevity. It is identified as the oldest medicinal discipline in the world and is believed to have originated more than 5,000 years ago and is even now evolving. ${ }^{(39-41)}$ It considers eradicating the root rationale of the malady a pivot strategy about suggested diets and health practices. Ayurveda houses varied features of distinct diseases, the therapeutics incorporating detoxification (Panchkarma) along with Yoga and pharmacopoeia; it is built entirely on natural mediums and all these therapies being conducted and proposed by a competent Vaidya (Ayurveda specialist). In Ayurveda, the medicinal preparations entail complex mixing of plant or animal-derived products, metals, and minerals for tending to the ailment. The ancient Indian scriptures citing these in specifics include the Rig Veda, Atharva Veda, Sushruta Samhita,
Charak Samhita and Ashtanga Hridayam Sangraha among others. In present times, the Ayurvedic practices are persist not only in India but also in developed nations like USA and European countries where these are either taken along the synthetic drugs to reduce the adverse effects done to the body or after successful completion of the course of these drugs so as to harmonize the body. ${ }^{(42)}$ This is attributed to its safety by manifesting minimum side effects, coming across with an extensive therapeutic domain, indicating precise outcomes and being pocket-friendly along with revitalization and nourishment of body tissues or organs in contrast to synthetic drugs that weaken or desecrate them by prolonged use. Although, like their synthetic counterparts, these herbal products when taken for a medicinal purpose, must be consumed under an approved guidance. In addition, a variety of antivirals are fabricated from plant herbal sources by replicating the structure of the extracted active ingredient. The aforesaid are accepted as processed drugs with utilization of creating antiviral drugs on massive consignments through steps of semi-synthesis or chemical transformations owing to their inadequacy of interfering with the host cells. Acquiring the traits of both herbal medications and synthetic drugs, these are at edge entitling to exigency and are innocuous as well as reliable. ${ }^{(43)}$ These products are persistent for decades for the treatment of critical viral infections such as influenza, herpes, smallpox, hepatitis, and others. ${ }^{(44-47)}$ One quarter of the routine medicines hold plant-derived compounds, the topmost prominent being quinine, procured from Cinchona tree bark, and reformed into chloroquine besides hydroxychloroquine. Parallel is the account of taxol (periwinkle plant), aspirin (willow bark) and morphine (opium poppy). ${ }^{(48)}$ The immense benefit here is the controlled drug delivery in contrast to their herbal counterparts where it becomes a pitfall in their use. Hence, a combination of this sort of synthesized formulation sets off as a superior preference 
owing to synergistic sequel and generates a consequential therapeutic effect. ${ }^{(49)}$

A variety of Indian herbs have proven to be beneficial against infections and possess properties such as being antiviral, antibacterial and antifungal. ${ }^{(50-52)}$. Indian ancient scripts, written thousands of years ago, including Charak Samhita, mention simple remedies for approaching a fit well being. Even drinking lukewarm water throughout the day contributes to the harmony of the body. This alongside following a routine of practicing Yogasanas and meditation everyday leads to a blessed immunity. Also, relieving and managing stress in the body is an important aspect for reviving the immune system. In this case, even simple deep breathing can prove to be useful. Since these exercises primarily focus on breathing, the outcome is a strengthened respiratory system, which is the need of the hour for combating the novel coronavirus, as its main target is the lungs. Moreover, if a person is suffering from COVID19 infection but his or her immunity is well enough, the recovery can be swift. ${ }^{(53)}$

Herbs can be consumed in varied forms by anyone, be it taken as it is, such as tulsi/ basil leaves (Ocimum tenuiflorum), fennel seeds (Foeniculum vulgare), Indian gooseberry (Phyllanthus emblica), raisin (Vitis vinifera), neem (Azadirachta indica) or used in cooking, such as garlic (Allium sativum), ginger (Zingiber officinale), black pepper (Piper nigrum), cardamom (Elettaria cardamomum), turmeric (Curcuma longa), coriander (Coriandrum sativum), clove (Syzygium aromaticum), cumin (Cuminum cyminum), curry leaves (Murraya koenigii), bay leaves/bay laurel (Laurus nobilis). ${ }^{(54)}$ They can also be consumed as an ingredient in herbal tea or in lukewarm water, such as lemon (Citrus limon), cinnamon (Cinnamomum verum), peppermint (Mentha piperita), ginger, fennel seeds and tulsi or can be taken with hot milk like turmeric or in the form of extracted juice, such as from the stem of giloy/ heart-shaped moonseed (Tinospora cordifolia) or in the form of powder or capsules of giloy or ashwagandha/ Indian ginseng (Withania somnifera). ${ }^{(54)}$ (Figure 1).

The immune system is reinforced stronger through the nutrients. Inadequate nutrition contributes to a rise in infections whenever provoked by external stimuli and magnifies

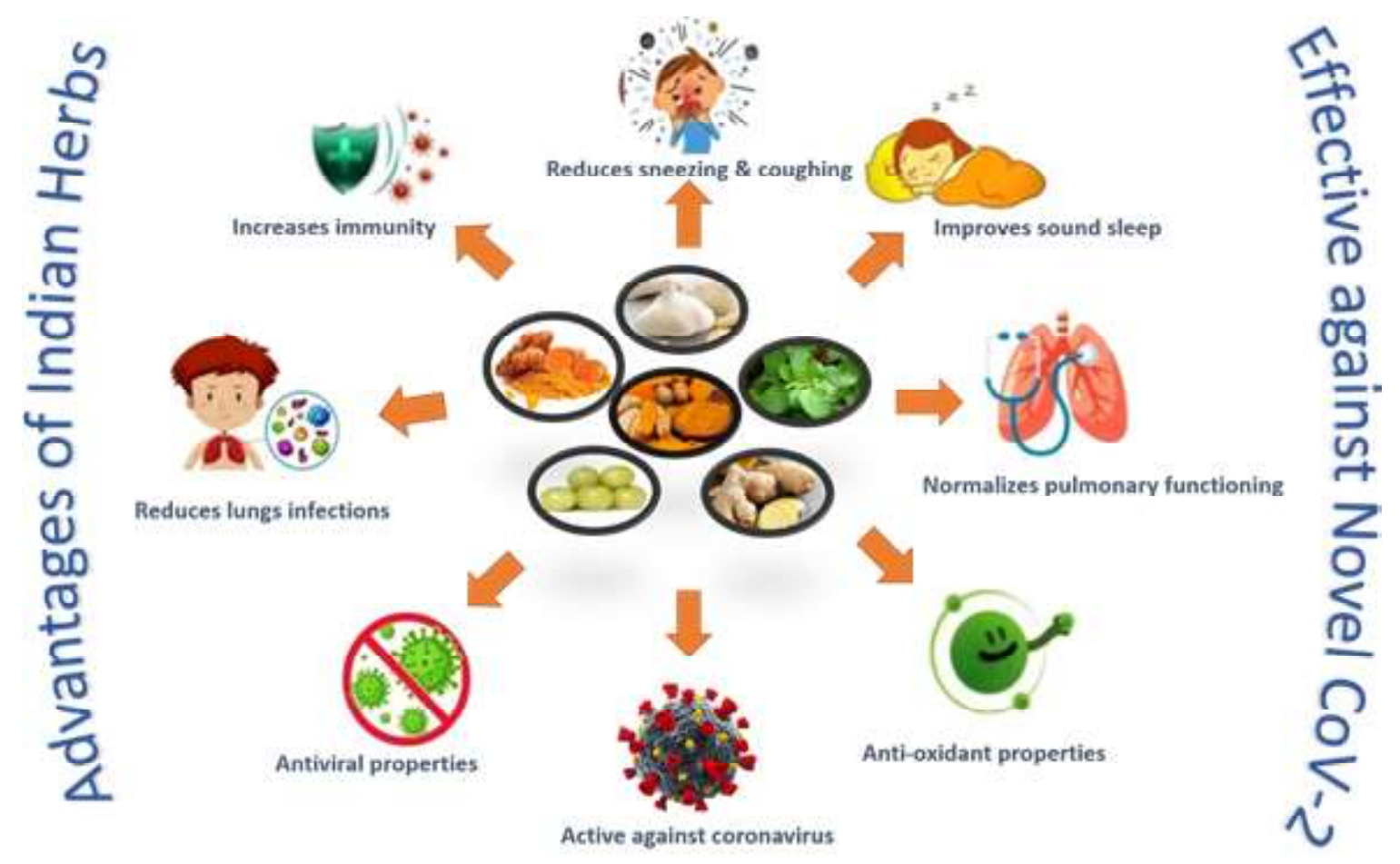

Figure 1. Showing the importance of Indian Herbs against novel CoV-2 virus ${ }^{(55-57)}$ 
vulnerability to manifestations and complexities arising from malfunctioning of the immune system. It is well established that immune function usually lessens with age or may even be hindered if one abandons upholding healthy nutrition.

Table 1 describes the contribution of these herbs to the immune system. The unparalleled property of these herbs is the numerous forms in which they can be consumed by an individual. Most of these can be consumed as they are, through cooking or in a concoction in tea or water or in the form of essential oils. For example, consider the herb tulsi, it can be eaten raw, or concocted with herbal tea, lukewarm water or even as chyawanprash (ancient Ayurvedic concoction of various natural herbs), or as an essential oil as well. ${ }^{(63-65)}$ Similar is the case with giloy, its powder obtained from the leaves, flower or roots can be consumed in concoction with hot water or ingested in the form of juice from its stems. This can prove to be convenient so as to reap the maximum benefits out of a particular herb.

In India, clinical trials are being conducted to comprehend the effect some of the herbs on the body for fighting against Covid-19. ${ }^{(6)} \mathrm{A}$ few

Table 1. Therapeutic properties of Indian herbs for immunity boosting

\begin{tabular}{|c|c|c|}
\hline Herb & $\begin{array}{l}\text { Main Active } \\
\text { Constituent }\end{array}$ & Therapeutic uses \\
\hline $\begin{array}{l}\text { Turmeric Curcuma } \\
\text { longa }\end{array}$ & Curcumin & $\begin{array}{l}\text { Antiviral (effective against flu, HIV, herpes, hepatitis), } \\
\text { antibacterial, anticancer, antioxidant, anti-inflammatory, } \\
\text { detoxifier }(50,51)\end{array}$ \\
\hline $\begin{array}{l}\text { Neem Azadirachta } \\
\text { indica }\end{array}$ & Azadirachtin & $\begin{array}{l}\text { Antiviral (effective against dengue), anti-diabetic, prevents } \\
\text { skin infections, antioxidant, anti-inflammatory, detoxifier }{ }^{(5)}\end{array}$ \\
\hline $\begin{array}{l}\text { Peppermint } \\
\text { Menthapiperita }\end{array}$ & $\begin{array}{l}\text { Menthol, Menthone } \\
\text { and Menthyl acetate }\end{array}$ & $\begin{array}{l}\text { Antiviral (effective against influenza and flu), antibacterial, } \\
\text { antioxidant, antifungal }(52,67)\end{array}$ \\
\hline $\begin{array}{l}\text { Tulsi } \\
\text { Ocimumtenuiflorum }\end{array}$ & $\begin{array}{l}\text { Methyl eugenol and } \\
\text { Methyl chavicol }\end{array}$ & $\begin{array}{l}\text { Antiviral (effective against flu, common cold), antibacterial, } \\
\text { anti- malarial, prevents skin infections }(56,68)\end{array}$ \\
\hline $\begin{array}{l}\text { Ginger Zingiber } \\
\text { officinale }\end{array}$ & $\begin{array}{l}\text { Gingerols, Zingerone } \\
\text { and Shogaols }\end{array}$ & $\begin{array}{l}\text { Antiviral (effective against flu, common cold), anti- } \\
\text { inflammatory, anti- nausea, antipyretic and analgesic }{ }^{(63)}\end{array}$ \\
\hline $\begin{array}{l}\text { Indian gooseberry } \\
\text { Phyllanthus } \\
\text { emblica }\end{array}$ & $\begin{array}{l}\text { Emblicanin A and B, } \\
\text { Gallic acid, Ellagic } \\
\text { acid }\end{array}$ & $\begin{array}{l}\text { Antiviral (effective against influenza and flu), anti-diabetic, } \\
\text { anticancer, antioxidant), anti-inflammatory }(70)\end{array}$ \\
\hline $\begin{array}{l}\text { Garlic Allium } \\
\text { sativum }\end{array}$ & Allicin and Alliinase & $\begin{array}{l}\text { Antiviral (common cold and flu), antifungal, anthelmintic, } \\
\text { anticancer, antihypertensive, antioxidant, anti- diabetic, } \\
\text { natural antibiotic }{ }^{(60)}\end{array}$ \\
\hline $\begin{array}{l}\text { Cinnamon } \\
\text { Cinnamomum } \\
\text { verum }\end{array}$ & $\begin{array}{l}\text { trans- } \\
\text { Cinnamaldehyde and } \\
\text { Eugenols }\end{array}$ & Antioxidant, antifungal, anti-diabetic, anti- inflammatory ${ }^{(72)}$ \\
\hline $\begin{array}{l}\text { Cumin Cuminum } \\
\text { cyminum }\end{array}$ & Cuminaldehyde & Antioxidant, anticancer, anti-diabetic, antibacterial ${ }^{(73)}$ \\
\hline Lemon Citrus limon & $\begin{array}{l}\text { Linanool and } \\
\text { Geraniol }\end{array}$ & $\begin{array}{l}\text { Anticancer, antioxidant, detoxifier, anti-nausea, protects } \\
\text { against skin diseases }{ }^{(74)}\end{array}$ \\
\hline $\begin{array}{l}\text { GiloyTinospora } \\
\text { cordifolia }\end{array}$ & $\begin{array}{l}\text { Berberine, } \\
\text { Tinocordiside and } \\
\text { Furanolactone }\end{array}$ & $\begin{array}{l}\text { Antioxidant, anticancer, antibacterial, anti-diabetic, stress } \\
\text { relieving, anti-inflammatory, anti-arthritic, antipyretic, } \\
\text { analgesic }(75,76)\end{array}$ \\
\hline $\begin{array}{l}\text { Ashwagandha } \\
\text { Withaniasomnifera }\end{array}$ & $\begin{array}{l}\text { Anaferine, Withanone } \\
\text { and Somniferinine }\end{array}$ & $\begin{array}{l}\text { Anti-inflammatory, anti-arthritic, stress relieving, } \\
\text { anticancer, antioxidant, natural antibiotic, anti-ageing (77) }\end{array}$ \\
\hline
\end{tabular}


Table 2. Herbal formulations in the clinical trial phase in India

\begin{tabular}{clcll}
\hline ID & \multicolumn{2}{c}{ Title } & Approach & \multicolumn{1}{c}{ Remarks } \\
\hline 226923 & $\begin{array}{l}\text { Siddha and biomedicine integrative } \\
\text { management of novel corona viddha } \\
\text { disease - a case report }{ }^{(78)}\end{array}$ & $\begin{array}{l}\text { Herbal formulations named Nilavembu } \\
\text { kudineer \& Chukku kanji used along with } \\
\text { allopathic medications with encouraging } \\
\text { results }\end{array}$
\end{tabular}

216624 Three case reports of moderate COVID19 infection managed through Ayurvedic approach ${ }^{(62,63)}$

216623 Efficacy of Ayurveda and Yoga in the management of SARS-CoV-2: two case reports ${ }^{(63)}$

206596 A retrospective analysis of the effect of the intervention of Arogya Kashayam in COVID-19 positive cases in Madhya Pradesh ${ }^{(79)}$

185937 Safety and efficacy of herbal extracts to restore respiratory health and improve innate immunity in COVID-19 positive patients with mild to moderate severity: A structured summary of a study protocol for a randomised controlled trial ${ }^{(80)}$

185935 Novel coronavirus (COVID-19) Unani etiological characteristics, clinical manifestations and Unani management (81)

165568 Outcomes of Ayurvedic care in a Covid19 patient with hypoxia- a case report ${ }^{(82)}$

164648 Ayurvedic treatment of COVID- Ayurveda 19/SARS-CoV-2: a case report ${ }^{(83)}$

164467 AYUSH 64, a polyherbal Ayurvedic formulation in Influenza-like illness results of a pilot study ${ }^{(84)}$
Ayurveda Success achieved from Kwatha and few others polyherbal formulations used and priority given to mental \& physical health of patients

Ayurveda Kwatha and few others polyherbal \& Yoga formulations used and focused on personalized holistic treatments for mild to moderate symptoms

Ayurveda A polyherbal formulation Arogya Kashayam-20 (AK-20) used as a vast case study in mildly symptomatic patients either independently or in combination with HCQ

Ayurveda Two polyherbal formulations (IP-1 \& IP2) along with calcinated zinc used and their safety and success in restoring respiratory health was accessed

Various Unani medicines and syrups tested against Covid-19 infection based on the symptoms manifested and history of other diseases in those patients

Ayurveda Numerous ayurvedic formulations employed along with Vitamin $\mathrm{C}$ and emphasized on treating hypoxia

Treatment carried out entirely based on Ayurveda using 4 polyherbal formulations: Sudarsana Churna, Dhanvantara Gutika, Talisadi Churna \& Deepanam

Ayurveda A polyherbal formulation AYUSH64 effective in treating mild to moderate cases of Covid-19 and is currently approved for use. of such herbally formulated medications have already been approved for use and more are either in preclinical or clinical trials. ${ }^{(66,67)} \mathrm{A}$ protocol has been shared by the Ministry of AYUSH, India regarding the management of Covid-19 with Ayurvedic approach and Yoga that also incorporates the use of AYUSH 64 and kwatha, both polyherbal medications. ${ }^{(68-70)}$ The recovery shown by the usage of such formulations in Covid-19 patients is encouraging. Some of the herbal formulations which are in the clinical trial phase are listed in Table 2.

The herbs serve by increasing the production of proteins named interferons and antibodies to trigger an immune response against viruses and therefore accelerate phagocytosis for impairing microorganisms and hence augment immunity by curbing the viral infection. ${ }^{(71)}$ Herbs contain 
hardly any chemicals that are unfavorable for the human health and seldom show any allergies or other adverse side-effects on the body, a phenomenon common to the synthetic drugs and medicines. In addition, the herbs can strengthen the immune system enough to withstand the infection and provide prompt symptomatic relief. Accordingly, an enhanced alternative these days is treating the infection using a combination of modern drugs and herbs. For instance, in the Chongqing region of China, doctors resorted to the drug Kaletra in combination with TCM to treat the patients and the results came out to be affirmative. ${ }^{(72)}$ In India, the doctors are relying chiefly on the drug hydroxychloroquine for the efficacious treatment of the symptoms of this calamitous disease. On that account, since India has plenteous sources of herbs and all of their properties are well established already, if India goes ahead with the exploration as to how the combination of herbs and drugs can be utilized for the sake of curtailing the side effects as well as the malefic repercussions of strong synthetic drugs used for treating COVID-19 patients, it would be a paramount leap in the field of Ayurveda as well as medicine.

\section{CONCLUSION}

It is a well-established fact that herbal plants and their derived products have contributed for ages in steering clear of ailments and meanwhile in this pandemic, they are benefitting again. Herbal plants have several active ingredients and when used in a complementary manner with synthetic drugs, the therapeutic effects can be collusive. Acknowledging that, the world must work towards its success and carry research in the direction of herbs and their products with synthetic drugs and accomplish in the outlook of attaining the utmost from these natural marvels since herbs are genesis of innumerable traits as discussed in this review. Until then, in this desperate stretch of SARS-CoV-2, heed should be at enhancing one's immunity by virtue of abounding herbs accessible in nature.

\section{ACKNOWLEDGMENTS}

The authors do acknowledge the efforts of all the doctors, health workers, scientists and researchers currently working against SARS$\mathrm{CoV}-2$. The authors greatly acknowledges the financial support from Science and Engineering Research Board (EEQ/2020/000437) New Delhi, India.

\section{CONFLICT OF INTEREST}

The authors declare no competing financial interest.

\section{CONTRIBUTORS}

AA and JS wrote the manuscript. RP designed the work and was overall corresponding author. All authors have read and approved the final manuscript.

\section{REFERENCES}

1. World Health Organization. Coronavirus disease (COVID-19): situation report 182. Geneva: World Health Organization;2020.

2. Boopathi S, Poma AB, Kolandaivel P. Novel 2019 coronavirus structure, mechanism of action, antiviral drug promises and rule out against its treatment. J Biomol Struct Dyn 2020:1-10. doi: 10.1080/07391102.2020.1758788.

3. Shereen MA, Khan S, Kazmi A, Bashir N, Siddique R. COVID-19 infection: origin, transmission, and characteristics of human coronaviruses. J Adv Res 2020;24:90-1. https://doi.org/10.1016/ j.jare.2020.03.005.

4. Sadhukhan P, Ugurlu MT, Hoque MO. Effect of COVID-19 on lungs: focusing on prospective malignant phenotypes. Cancers 2020;12:3822. doi: 10.3390/cancers12123822.

5. Subbarao K, Mahanty S. Respiratory virus infections: understanding COVID-19. Immunity 2020;52:905-9. doi: 10.1016/j.immuni.2020.05.004.

6. Ahn DG, Shin HJ, Kim MH, et al. Current status of epidemiology, diagnosis, therapeutics, and vaccines for novel coronavirus disease 2019 (COVID-19). J Microbiol Biotechnol 2020;30:31324. doi: 10.4014/jmb.2003.03011.

7. Guan WJ, NiZY, Hu Y, et al. Clinical characteristics of coronavirus disease 2019 in China. N Engl J 
Med 2020;382:1708-20. DOI: 10.1056/ NEJMoa2002032.

8. Santos A, Chacón J, Rosas-Acosta, G, editors. Influenza A virus multiplication and the cellular SUMOylation system. In: Viral replication. German Rosas-Acosta: IntechOpen;2013. DOI: 10.5772/54351.

9. Pushpa R, Nishant R, Navin K, Pankaj G. Antiviral, potential of medicinal plants: an overview. Int Res J Pharmacy 2013;4:8-16. DOI: 10.7897/2230-840704603.

10. Kang K, Bachu M, Park SH, et al. IFN-ã selectively suppresses a subset of TLR4-activated genes and enhancers to potentiate macrophage activation. Nat Comm 2019;10:1-14. https://doi.org/10.1038/ s41467-019-11147-3.

11. Ivashkiv LB. IFNã: signalling, epigenetics and roles in immunity, metabolism, disease and cancer immunotherapy. Nat Rev Immunol 2018;18:54558. doi: 10.1038/s41577-018-0029-Z.

12. Karimi Y, Giles E, Vahedi F, et al. IFN-ã signalling regulates RAW 264.7 macrophage activation, cytokine production, and killing activity. Innate Immun 2020;26:172-82 . doi: 10.1177/ 1753425919878839.

13. Jones JE, Le Sage V, Lakdawala SS. Viral and host heterogeneity and their effects on the viral life cycle. Nat Rev Microbiol 2021;19, 272?82. https:/ /doi.org/10.1038/s41579-020-00449-9.

14. Han W, Quan B, Guo Y, et al. The course of clinical diagnosis and treatment of a case infected with coronavirus disease 2019. J Med Virol 2020;92:4613. DOI: $10.1002 /$ jmv.25711.

15. Trivedi A, Sharma S, Ashtey B. Investigational treatments for COVID-19. Pharma J 2020;304. DOI:10.1211/PJ.2020.20208051.

16. World Health Organization. COVID-19 clinical management: living guidance. Geneva: World Health Organization;2020.

17. Sanders JM, Monogue ML, Jodlowski TZ, Cutrell JB. Pharmacologic treatments for coronavirus disease 2019 (COVID-19). JAMA 2020;323: 182436. doi: 10.1001/jama.2020.6019.

18. Huang L, Chen Y, Xiao J, et al. Progress in the research and development of anti-COVID-19 drugs. Front Public Health 2020;8: 365. https:// doi.org/10.3389/fpubh.2020.00365.

19. Zhao Z, Li Y, Zhou L, et al. Prevention and treatment of COVID-19 using traditional Chinese medicine: a review. Phytomedicine 2021; 85:153308. doi: 10.1016/j.phymed.2020.153308.

20. Qiu Q, Huang Y, Liu X, et al. Potential therapeutic effect of traditional Chinese medicine on coronavirus disease 2019: a review. Front Pharmacol 2020;11:570893. doi: 10.3389/ fphar.2020.570893.

21. Dai YJ, Wan SY, Gong SS,Liu SC, Li F, Kou JP. Recent advances of traditional Chinese medicine on the prevention and treatment of COVID-19. Chin J Nat Med 2020;18:881-9. doi: 10.1016/S18755364(20)60031-0.

22. Xu J, Zhang Y. Traditional Chinese medicine treatment of COVID-19. Complement Ther Clin Pract 2020;101165. doi: 10.1016/j.ctcp.2020.101165.

23. Zhang M, Huang J, Wu X, Lv L, Huang A, Zhu S. Internal treatment in traditional Chinese medicine for patients with COVID-19: a protocol for systematic review and meta-analysis. Medicine 2020;99:e23739. doi: 10.1097/ MD.0000000000023739.

24. Yu MA, Shen AK, Ryan MJ, Boulanger LL. Coordinating COVID-19 vaccine deployment through the WHO COVID-19 partners platform. Bull World Health Organization 2021;99:171-1A. doi: 10.2471/BLT.21.285550.

25. Calder P. Nutrition, immunity and COVID-19. BMJ Nutr Prev Health 2020;3:74-92. doi: 10.1136/ bmjnph-2020-000085.

26. Food Agriculture Organization. Maintaining a healthy diet during the COVID-19 pandemic. Rome: Food Agriculture Organization;2020. https://doi.org/10.4060/ca8380enNations,

27. Giménez VMM, Inserra F, Tajer CD, et al. Lungs as target of COVID-19 infection: protective common molecular mechanisms of vitamin $\mathrm{D}$ and melatonin as a new potential synergistic treatment. Life Sci 2020; 254:117808. doi: 10.1016/ j.lfs.2020.117808.

28. Anand U, Jacobo-Herrera N, Altemimi A, Lakhssassi N. A comprehensive review on medicinal plants as antimicrobial therapeutics: potential avenues of biocompatible drug discovery. Metabolites 2019;9:258. doi: 10.3390/ metabo9110258.

29. Thomford NE, Senthebane DA, Rowe A, et al. Natural products for drug discovery in the $21 \mathrm{st}$ century: innovations for novel drug discovery. Int J Mol Sci 2018;19:1578. doi: 10.3390/ ijms19061578.

30. Koparde AA, Doijad RC, Magdum CS. Natural products in drug discovery. In: Perveen S, AlTaweel A, editors. Pharmacognosy - medicinal plants. IntechOpen;2019. DOI: 10.5772/ intechopen.82860.

31. World Health Organization. WHO global report on traditional and complementary medicine. Geneva: World Health Organization;2019.

32. Jain C, Khatana S, Vijayvergia R. Bioactivity of secondary metabolites of various plants: a review. Int JPharm Sc Res 2019;10:494-504. DOI: 10.13040/ IJPSR.0975-8232.10(2).494-04. 
33. Shaito A, Thuan DTB, Phu HT, et al. Herbal medicine for cardiovascular diseases: efficacy, mechanisms, and safety. Front Pharmacol 2020; 11:422. doi: 10.3389/fphar.2020.00422.

34. Verma S, Gupta M, Popli H, Aggarwal G. Diabetes mellitus treatment using herbal drugs. Int $\mathrm{J}$ Phytomed 2018;10: 1-10. DOI:10.5138/ 09750185.2181.

35. Pal RS, Pal Y, Saraswa N, Wal P, Wal A. Current review on herbs for derma care. Open Dermatol J 2019;13:41-6. DOI: 10.2174/1874372201913010041.

36. Gorlenko CL, Kiselev HY, Budanova EV, Zamyatnin AA, Ikryannikova LN. Plant secondary metabolites in the battle of drugs and drug-resistant bacteria: new heroes or worse clones of antibiotics? Antibiotics 2020;9:170. doi: 10.3390/antibiotics9040170.

37. Tungmunnithum D, Thongboonyou A, Pholboon A, Yangsabai A. Flavonoids and other phenolic compounds from medicinal plants for pharmaceutical and medical aspects: an overview. Medicines 2018;5:93. doi: 10.3390/ medicines5030093.

38. Karak P. Biological activities of flavonoids: an overview. Int J Pharm Sci Res 2019;10: 1567-74. DOI: 10.13040/IJPSR.0975-8232.10(4).1567-74.

39. Jaiswal YS, Williams LL. A glimpse of Ayurveda? the forgotten history and principles of Indian traditional medicine. J Tradit Complement Med 2017;7:50-3. doi: 10.1016/j.jtcme.2016.02.002.

40. Dubey S, Gupta A, Mishra M, Singh S. Indian health and medicinal system: from ancient India to present world. World J Pharm Res 2018;7:36273.

41. Saini A. Physicians of ancient India. J Family Med Prim Care 2016;5:254-8. doi: 10.4103/2249. 4863.192322.

42. Wegener T. Patterns and trends in the use of herbal products, herbal medicine and herbal medicinal products. Int J Complement Alt Med 2017;9:00317. DOI: 10.15406/ijcam.2017.09.00317.

43. Süntar I. Importance of ethnopharmacological studies in drug discovery: role of medicinal plants. Phytochem Rev 2020;19:1199-209. https://doi.org/ 10.1007/s11101-019-09629-9.

44. Ben-Shabat S, Yarmolinsky L, Porat D, Dahan A. Antiviral effect of phytochemicals from medicinal plants: applications and drug delivery strategies. Drug Deliv Transl Res 2020;10:354-67. https:// doi.org/10.1007/s13346-019-00691-6.

45. John KMM, Enkhtaivan G, Ayyanar M, Jin K, Yeon JB, Kim DH. Screening of ethnic medicinal plants of South India against influenza (H1N1) and their antioxidant activity. Saudi J Biol Sci 2015;22:191-7. doi: 10.1016/j.sjbs.2014.09.009.
46. Ghildiyal R, Prakash V, Chaudhary VK, Gupta V, Gabrani R. Phytochemicals as antiviral agents: recent updates. In: Swamy M, editor. Plantderived bioactives. Singapore: Springer, Singapore;2020.p.270-95. https://doi.org/10.1007/ 978-981-15-1761-7-12.

47. Garcia S. Pandemics and traditional plant-based remedies: a historical-botanical review in the era ofCOVID19. Front Plant Sci 2020; 11: 571042. doi: 10.3389/fpls.2020.571042.

48. Atanasov AG, Waltenberger B, Pferschy-Wenzig $E M$, et al. Discovery and resupply of pharmacologically active plant-derived natural products: a review. Biotechnol Adv 2015;33:1582614. doi: 10.1016/j.biotechadv.2015.08.001.

49. Saraswat J, Singh P, Patel R. A computational approach for the screening of potential antiviral compounds against SARS-CoV-2 protease: ionic liquid vs herbal and natural compounds. J Mol Liq 2021;326:115298. doi: 10.1016/ j.molliq.2021.115298.

50. Moghadamtousi SF, Kadir HA, Hassandarvish P, Tajik H, Abubakar S, Zandi K. A review on antibacterial, antiviral, and antifungal activity of curcumin. Biomed Res Int 2014;2014:186864. doi: 10.1155/2014/186864.

51. Praditya D, Kirchhoff L, Brüning J, Rachmawati H, Steinmann J, Steinmann E. Anti-infective properties of the golden spice curcumin. Front Microbiol 2019;10:912. doi: 10.3389/ fmicb.2019.00912.

52. Shah A, Krishnamurth R. Swine flu and its herbal remedies. Int J Eng Sci 2013;2:68-78.

53. Yazdanpanah F, Hamblin MR, Rezaei N. The immune system and COVID-19: friend or foe? Life Sci2020;256:117900. doi: 10.1016/j.lfs.2020.117900.

54. Vellingiri B, Jayaramayya K, Iyer M, et al. COVID19: a promising cure for the global panic. Sci Total Environ 2020;725:138277. doi: 10.1016/ j.scitotenv.2020.138277.

55. Bhavsar A, Damani A. A comparative study of the performance of selected mutual fund growth schemes from the private sector and public sector schemes in India. Anvesha 2014;7:1-9.

56. Cohen MM. Tulsi - Ocimum sanctum: a herb for all reasons. J Ayurveda Integr Med 2014;5:251-9. doi: 10.4103/0975-9476.146554.

57. Santhosha S, Jamuna P, Prabhavathi S. Bioactive components of garlic and their physiological role in health maintenance: a review. Food Biosci 2013;3:59-74. DOI:10.1016/j.fbio.2013.07.001.

58. Yamani HA, Pang EC, Mantri N, Deighton MA. Antimicrobial activity of tulsi (Ocimum tenuiflorum) essential oil and their major constituents against three species of bacteria. 
Front Microbiol 2016;7:681. doi: 10.3389/ fmicb.2016.00681.

59. Jamshidi N, Cohen MM. The clinical efficacy and safety of tulsi in humans: a systematic review of the literature. Evid Based Complement Alternat Med 2017;2017:9217567. doi: 10.1155/2017/ 9217567.

60. Kumar A, Rahal A, Chakraborty S, Tiwari R, Latheef SK, Dhama K. Ocimum sanctum (tulsi): a miracle herb and boon to medical science - a review. Int J Agronomy Plant Prod 2013;4:1580-9.

61. Aiya Y, Chandru V, Chatterjee M, et al. India's resurgence of COVID-19: urgent actions needed. Lancet 2021;397:2232-4. doi: 10.1016/S01406736(21)01202-2.

62. Jyothi PA, Dileep A, Devarajan D, et al.. Three case reports of moderate COVID-19 infection managed through Ayurvedic approach. J Ayurveda Case Reports 2020;3:84-90. DOI: 10.4103/jacr.jacr_57_20.

63. Mahto RR, Jyothi A, Dileep A, Shukla A, Gauri A. Efficacy of Ayurveda and Yoga in the management of SARS-CoV-2: two case reports. J Ayurveda Case Reports 2020;3:127-32. DOI: 10.4103/jacr.jacr_9_21.

64. Nugraha RV, Ridwansyah H, Ghozali M, Khairani AF, Atik N. Traditional herbal medicine candidates as complementary treatments for COVID-19: a review of their mechanisms, pros and cons. Evidence-Based Complementary Alternative Medicine 2020, Article ID 2560645, 12 pages. https://doi.org/10.1155/2020/2560645.

65. Wan S, Xiang Y, Fang W, et al. Clinical features and treatment of COVID-19 patients in northeast Chongqing. J Med Virol 2020;92:797-806. doi: 10.1002/jmv.25783.

66. Aiyar Y, Chandru V, Chatterjee M, et al. India's resurgence of COVID-19: urgent actions needed. Lancet 2021; 397:2232-4. doi: 10.1016/S01406736(21)01202-2.

67. Trevisan SC C, Menezes APP, Barbalho SM, Guiguer ÉL. Properties of Mentha piperita: a brief review. World J Pharm Med Res 2017;3:309-13.

68. Kumar D, Arya V, Kaur R, Bhat ZA, Gupta VK, Kumar V. A review of immunomodulators in the Indian traditional health care system. J Microbiol Immunol Infect 2012;45:165-84. doi: 10.1016/ j.jmii.2011.09.030.

69. Mao QQ, Xu XY, Cao SY, Gan RY, Corke H, Li HB. Bioactive compounds and bioactivities of ginger (Zingiber officinale Roscoe). Foods 2019;8: 185. doi: 10.3390/foods8060185.

70. Chang JS, Wang KC, Yeh CF, Shieh DE, Chiang LC. Fresh ginger (Zingiber officinale) has antiviral activity against human respiratory syncytial virus in human respiratory tract cell lines. J Ethnopharmacol 2013;145:146-51. doi: 10.1016/ j.jep.2012.10.043.

71. Kumar KS, Bhowmik D, Dutta A, et al. Recent trends in potential traditional Indian herbs Emblica officinalis and its medicinal importance. J Pharmacog Phytochem 2012;1:24-32.

72. Ranasinghe P, Pigera S, Premakumara GS, Galappaththy P, Constantine GR, Katulanda P. Medicinal properties of 'true' cinnamon (Cinnamomum zeylanicum): a systematic review. BMC Complemt Altern Med 2013;13:275. doi: 10.1186/1472-6882-13-275.

73. Sowbhagya HB. Chemistry, technology, and nutraceutical functions of cumin (cuminum cyminum $L$ ): an overview. Crit Rev Food Sci Nutr 2013;53:1-10. doi: 10.1080/10408398.2010.500223.

74. Klimek-Szczykutowicz M, Szopa A, Ekiert H. Citrus limon (Lemon) phenomenon - a review of the chemistry, pharmacological properties, applications in the modern pharmaceutical, food, and cosmetics industries, and biotechnological studies. Plants (Basel) 2020;9:119. doi: 10.3390/ plants9010119Plants 9, 119.

75. Josh G, Kaur R. Tinospora cordifolia: a phytopharmacological review. Int J Pharma Sci Res 2016;7:890-7. 10.13040/IJPSR.09758232.7(3).890-97.

76. Mittal J, Sharma MM, Batra A. Tinospora cordifolia: a multipurpose medicinal plant - a review. J Med Plants Stud 2014;2:32-47.

77. Pratibha C, Madhumati B, Akarsh P. Therapeutic properties and significance of different parts of Ashwagandha - a medicinal plant. Int J Pure App Biosci 2013;1:94-101.

78. Wilson E, Vinayak S, Kanakavalli K. Siddha and biomedicine integrative management of novel corona virus disease-a case report. Int J AYUSH Case Reports 2020;4:154-60. https://doi.org/ https://doi.org/10.52482/ijacare.v4i3.162.

79. Shukla U, Srivastava S, Gupta P, Ujjaliy N. A retrospective analysis of the effect of the intervention of Arogya Kashayam in COVID-19 positive cases in Madhya Pradesh. An Int Q J Res Ayurveda 2019;40: 209-15. DOI: 10.4103/ ayu.ayu_365_20.

80. Rangnekar H, Patankar S, Suryawanshi K, Soni P. Safety and efficacy of herbal extracts to restore respiratory health and improve innate immunity in COVID-19 positive patients with mild to moderate severity: a structured summary of a study protocol for a randomised controlled trial. Trials 2020; 21: 943. doi: 10.1186/s13063-02004906-x. 
81. Khan AA, Kumar P. Novel coronavirus (COVID19) etiological characteristics, clinical manifestations and Unani management. Int $\mathbf{J}$ Herbal Med 2021;9:111-4.

82. Joshi JA, Puthiyedath R. Outcomes of Ayurvedic care in a COVID-19 patient with hypoxia- a case report. J Ayurveda Integr Med 2020; https:// doi.org/10.1016/j.jaim.2020.10.006.
83. Girija P, Sivan N. Ayurvedic treatment of COVID19/SARS-CoV-2: A case report. J Ayurveda Integr Med 2020. https://doi.org/10.1016/j.jaim.2020. 06.001 .

84. Gundeti MS, Bhurke LW, Mundada PS, et al. AYUSH 64, a polyherbal Ayurvedic formulation in influenza-like illness - results of a pilot study. J Ayurveda Integr Med 2020. https://doi.org/ 10.1016/j.jaim.2020.05.010. 